Jurnal Geocelebes Vol. 5 No. 2, Oktober 2021, 173 - 181

\title{
PENENTUAN EPISENTRUM DAN HIPOSENTRUM GEMPA BUMI MENGGUNAKAN METODE GRID SEARCH DI ANTELOPE VALLEY, CALIFORNIA
}

\author{
Ambrosius Hernawan Wibisono*, Restu Wildanu Ahadi, Sultan Al Ghifari, Ilham Dani, dan \\ Syamsurijal Rasimeng
}

Teknik Geofisika, Universitas Lampung, Jl. Prof. Sumatri Brojonegoro No. 1, Lampung 35145, Indonesia.

*Corresponding author. Email: ambroambro712@gmail.com

Manuscript received: 20 July 2021; Received in revised form: 11 October 2021; Accepted: 22 October 2021

\begin{abstract}
Abstrak
Penentuan titik episenter (titik gempa terekam di permukaan bumi) dan hiposenter (titik gempa terekam di bawah permukaan bumi) dapat dilakukan dengan perhitungan numerik. Penelitian ini menentukan titik episenter dan titik hiposenter gempa yang terjadi di Antelope Valley, California, Amerika Serikat tahun 2021 dengan kekuatan sebesar magnitudo 6.0 pada geografis lintang $38.507^{\circ} \mathrm{LU}$ dan bujur $119.499^{\circ}$ BB. Gempa terekam di tiga stasiun terdekat, yaitu stasiun NV31, PASC, dan CMB. Perkiraan titik gempa berada di tengah-tengah ketiga stasiun tersebut, sehingga data perekaman gempa pada ketiga stasiun tersebut sangat penting karena dianggap paling akurat. Penelitian ini menggunakan metode Grid Search dengan plotting 2D dan 3D. Pengolahan data menggunakan Google Colaboratory, dan SeisGram2K v7. Data perhitungan merujuk informasi resmi dari situs USGS (United States Geological Survey). Berdasarkan perhitungan, diperoleh hasil plotting 2D bahwa titik episenter pada lintang $39.255^{\circ} \mathrm{LU}$ dan bujur $119.833^{\circ} \mathrm{BB}$. Hasil plotting 3D menunjukkan titik hiposenter pada lintang $38.627^{\circ} \mathrm{LU}$, bujur $119.788^{\circ} \mathrm{BB}$, dengan kedalaman $18 \mathrm{Km}$.
\end{abstract}

Kata Kunci: episenter; gempa bumi; grid search; hiposenter; SeisGram2K v7.

\begin{abstract}
Determination of the epicenter point (the epicenter point recorded on the earth's surface) and the hypocenter (the epicenter point recorded below the earth's surface) earthquakes can be done with numerical calculations. This study determined the epicenter and hypocenter point of the earthquake that occurred in Antelope Valley, California, United States in 2021 with a magnitude 6.0 at geographic latitude $38.507^{\circ} \mathrm{NL}$ and longitude $119.499^{\circ} \mathrm{WL}$. The quake was recorded at three nearby stations, NV31, PASC, and CMB. The estimated point of the earthquake is in the middle of the three stations, so earthquake recording data at all three stations is very important because it is considered the most accurate. The study used Grid Search by plotting 2D and 3D method. Data processing using Google Collaboratory, and SeisGram2K v7. The calculation data refers to official information from the USGS (United States Geological Survey) website. Based on calculation, obtained the result of plotting 2D that the epicenter points at latitude $39,255^{\circ} \mathrm{NL}$ and longitude $119.833^{\circ} \mathrm{WL}$. The results of $3 \mathrm{D}$ plotting show the hypocenter point at latitude $38,627^{\circ} \mathrm{NL}$, longitude $119,788^{\circ} \mathrm{WL}$, with a depth of $18 \mathrm{Km}$.
\end{abstract}

Keywords: earthquake; epicenter; grid search; hypocenter; SeisGram2K v7. 


\section{Pendahuluan}

Fisiografis daratan Amerika bagian utara terbagi atas dasar kesamaan karakteristik wilayahnya. Bentuk pengklasifikasian didasarkan pada karakteristik batuan, bentuk lahan, iklim, tanah, vegetasi, drainase, maupun sejarah geologi, dan geomorfologinya. Pengaruh asal fisiografis tersebut oleh karena adanya aktivitas tektonik, seperti penunjaman Lempeng Farallon terhadap Lempeng Amerika Utara, dan pergerakan transform antara Lempeng Pasifik dengan Lempeng Amerika Utara (DeCourten, 2008). Aktivitas tektonik tersebut merupakan pengaruh seismik dari dalam bumi yang mendasari dipilihnya daerah tersebut sebagai tempat penelitian. Maka dari itu, diperlukan sebuah metode untuk mendeteksi gelombang seismik tersebut yang dikenal oleh masyarakat awam sebagai gempa bumi. Berdasarkan letak geografis Pegunungan Sierra Nevada berada di California dengan mengarah barat laut dan membentang sejauh lebih dari 700 km. Gunung Whitney sebagai puncak tertinggi daratan Amerika Serikat dengan ketinggian 4418 mdpl terletak di kawasan Pegunungan Sierra Nevada. Batholit merupakan batuan dasar yang mendominasi Pegunungan Sierra Nevada pada era Mesozoik yang terletak di batas Amerika Utara bagian barat karena hasil dari subduksi Lempeng Farallon (Tanjung, 2018). Strike-slip aktif dan sesar normal di sepanjang batas timur Sierra Nevada terutama mengakomodasi translasi ke arah barat laut dari Lempeng Mikro Sierra Nevada-Central Valley. Sesar strike-slip yang berbatasan dengan Lempeng Mikro Sierra bagian timur adalah sub-paralel dengan lingkaran kecil di sekitar kutub Euler Sierra Nevada-Amerika Utara. Sesar normal dari sistem sesar frontal Sierra Nevada memiliki strike $45^{\circ}$ searah jarum jam dari lintasan lingkaran kecil dan menunjukkan pola en echelon, konsisten dengan formasi dalam rezim transcurrent dekstral. Kinematik inversion pada focal mechanisms gempa dari Sabuk Walker
Lane yang berbatasan dengan Sierra Nevada timur menunjukkan bahwa deformasi seismogenik terutama dicirikan oleh geser horizontal dan penipisan kerak miring. Sesar normal di sepanjang sebagian besar front jangkauan Sierran timur dengan demikian tampaknya terutama mengakomodasi translasi lempeng mikro daripada pengangkatan Sierran atau perluasan basin dan rentang regional (Unruh dkk., 2003)

Gempa bumi adalah fenomena yang menimbulkan getaran di bumi karena adanya pergerakan lempeng, aktivitas vulkanik, dan runtuhan batuan (Rysnawati dkk., 2017). Terjadinya gempa bumi tektonik diakibatkan pergerakan lempeng yang terakumulasi. Gelombang seismik bergerak sebagai efek energi yang menghantarkan getaran atau goncangan tanah sehingga dirasakan di permukaan bumi (Sunarjo dkk., 2012). Ketika gempa merambat pada batuan maka terjadi elastisitas. Padatan elastis dapat menyebabkan pergerakan permukaan setelah gempa karena merambatkan berbagai fase gelombang. Gelombang yang merambat, berupa gelombang $\mathrm{P}$ dan gelombang S. Selain itu terdapat gelombang Rayleigh dan gelombang Love sebagai gelombang kombinasi (Palupi dan Raharjo, 2020). Penelitian akan fenomena gempa bumi memunculkan pengetahuan akan dampak akibat gempa bumi, pemodelan gempa bumi, dan diketahuinya informasi untuk mempelajari parameterparameter kegempaan (Arimuko dkk., 2019). Parameter kegempaan berupa waktu tiba gelombang gempa (origin time), sumber asal (hiposenter) dan magnitudo (Rahman dan Santosa, 2013).

Hiposenter merupakan titik pusat terjadinya gempa bumi pada kedalaman tertentu. Menurut Kusuma (2018) ada beberapa jenis gempa bumi berdasarkan kedalaman hiposenternya, yang pertama gempa bumi dangkal dengan kedalaman pusat kurang dari 70 Kilometer, gempa bumi sedang 
dengan kedalaman pusat $70-300$ Kilometer. Gempa bumi dalam dengan kedalaman pusat $300-700$ Kilometer. Dalam seismologi, penentuan lokasi hiposenter dapat diketahui menggunakan perhitungan numerik berbasis komputer. Keunggulan dari penggunaan perhitungan numerik yaitu untuk mendapatkan hasil dengan cepat (Arimuko dkk., 2019).

Penelitian ini menggunakan perhitungan numerik untuk menentukan titik episenter dan titik hiposenter gempa yang terjadi di Valley, California, Amerika Serikat tahun 2021 melalui data yang terekam oleh stasiun gempa. Pemilihan stasiun gempa pada daerah penelitian didasarkan adanya rentang letak antar stasiun yang relatif dekat, sehingga menambah tingkat keakuratan penelitian ini. Pemilihan daerah penelitian didasarkan keterbaruan informasi data gempa yang terekam oleh stasiun gempa dalam kurun waktu terkini.
Sehingga belum adanya pengolahan akan data gempa tersebut. Maka perlu ditelaah letak hiposenter dan episenter gelombang gempa tersebut sebagai sebuah informasi fenomena yang terjadi dalam kurun waktu saat ini di daerah penelitian. Metode perhitungan menggunakan metode Grid Search dengan plotting 2D dan 3D, sedangkan pengolahan data menggunakan Google Colaboratory berbasis Phyton 3, dan SeisGram2K v7. Data perhitungan merujuk informasi resmi dari situs USGS.

\section{Metode Penelitian}

Perangkat utama/ peralatan penunjang penelitian ini berupa perangkat keras (hardware), yaitu laptop dengan spesifikasi core i7 dan RAM 8 GB. Perangkat lunak (software) untuk mengolah data, yaitu program Google Colaboratory, dan SeisGram2K v7.0.0X10.

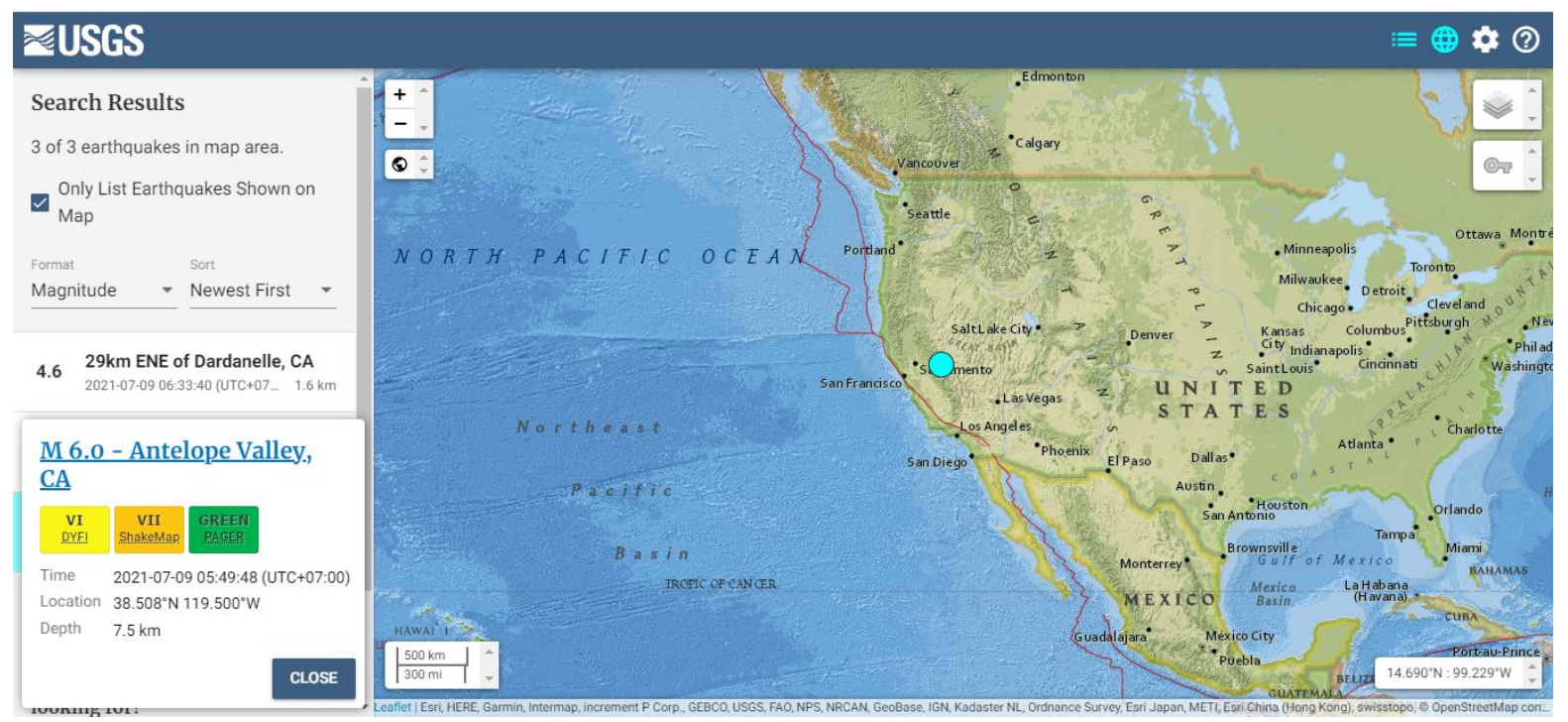

Gambar 1. Lokasi episenter gempa (lingkaran warna biru muda) di Antelope Valley, California, berdasarkan USGS.

Gambar 1 menunjukan data lokasi episenter penelitian sebagai data validasi/ rujukan yang dirilis oleh USGS (United States Geological Survey), sedangkan data perhitungan yang dipergunakan dalam penelitian ini menggunakan katalog data yang dirilis situs IRIS (Incorporated Research Institutions for Seismology). Data penelitian diunduh pada katalog IRIS tanggal 8 Juli 2021, pukul 22:49:48 UTC merupakan data gempa dengan kekuatan magnitudo 6.0 dengan kedalaman $7,45 \mathrm{~km}$ berada di Antelope Valley, di negara bagian California, Amerika Serikat. Dengan lokasi titik gempa terukur lintang $38.5075^{\circ} \mathrm{LU}$, bujur $119.499833^{\circ}$ BB. Penelitian akan titik gempa ini terekam oleh sebanyak 3 stasiun pengamatan gempa terdekat, yaitu $\mathrm{CMB}$ (Columbia College) di Columbia, California, Amerika Serikat dengan 
koordinat lintang $38,03^{\circ} \mathrm{LU}$, bujur $120,39^{\circ}$ BB, stasiun NV31 (NVAR Array Site 31) di Mina, Nevada, Amerika Serikat dengan koordinat lintang $38,43^{\circ} \mathrm{LU}$, bujur $118,16^{\circ}$ $\mathrm{BB}$, dan stasiun PASC (Art Center College of Design (GSN-affiliate)) di Los Angeles, Amerika Serikat dengan koordinat lintang $34,17^{\circ} \mathrm{LU}$, bujur $118,19^{\circ} \mathrm{BB}$.

Pengolahan data dilakukan dengan metode Grid Search untuk menemukan hasil titik episenter dan titik hiposenter gempa. Metode ini dapat menghasilkan plotting berbentuk 2D untuk mengetahui titik episenter dan 3D untuk mengetahui titik hiposenter. Metode Grid Search diketahui sebagai solusi atas inversi non-linier yang menyertakan pendekatan global (Nugroho dkk., 2007). Metode Grid Search juga mengevaluasi rentang pencarian dari sumber gempa bumi. Definisi dari mengevaluasi setiap titik adalah menghitung nilai $t_{i}^{\text {cal }}$ (waktu tiba gelombang pada stasiun ke-I hasil perhitungan) di titik tersebut. Nilai $t_{i}^{\text {cal }}$ setiap stasiun akan dibandingkan dengan $t_{i}^{o b s}$ (waktu tiba gelombang pada stasiun ke-i) setiap stasiun. Jika dievaluasi setiap titik, maka akan ada sebuah titik yang memiliki nilai $t_{i}^{c a l}$ mirip dengan $t_{i}^{o b s}$. Titik ini lah yang berpeluang menjadi titik sumber gempa. Pengukuran kemiripan nilai $t_{i}^{\text {cal }}$ dan $t_{i}^{\text {obs }}$ adalah dengan menghitung nilai error root mean square (RMS). Metode inversi digunakan untuk memperoleh informasi akan suatu sistem fisika berdasarkan observasi terhadap sistem tersebut dimana dalam bentuk metode matematika dan statistika (Grandis, 2009). Metode ini adalah kebalikan dari forward modelling. Metode inversi terbagi atas inversi linier dan non-linier. Inversi diterapkan sebagai cara mencari minimum suatu fungsi obyektif yang menyatakan selisih antara data pengamatan dan data teoritis untuk suatu model tertentu. Secara general, data geofisika bersifat non-linier, dikarenakan berupa data yang acak atau random, yang dapat dijumpai pada data gempa bumi dari beberapa stasiun yang tentu saja berbeda koordinat pada setiap stasiun. Pengolahan data dapat dilakukan dengan picking data terlebih dahulu oleh program SeisGram2K untuk menentukan waktu tiba gelombang primer (P) dan sekunder (S) serta interval keduanya dari setiap stasiun gempa. Informasi data tersebut kemudian dapat diolah untuk mendapatkan $t_{o}$ atau origin time gempa menggunakan Diagram Wadati. Kemudian dilanjutkan untuk mengolah data dengan Google Colaboratory untuk menentukan titik episenter yang berbentuk plotting 2D. Di samping itu, dihasilkan juga plotting 3D untuk mendapatkan titik hiposenter. Proses dalam mengolah data gempa bumi memerlukan adanya $t_{i}^{\text {obs }}$ pada setiap stasiun pengamat gempa bumi. $t_{i}^{o b s}$ ini diperlukan untuk mengetahui waktu tempuh gelombang $\mathrm{P}$ yang tercatat pertama kali pada stasiun pencatat. Adapun tahapan penelitian digambarkan pada diagram alir yang dapat dilihat pada Gambar 2.

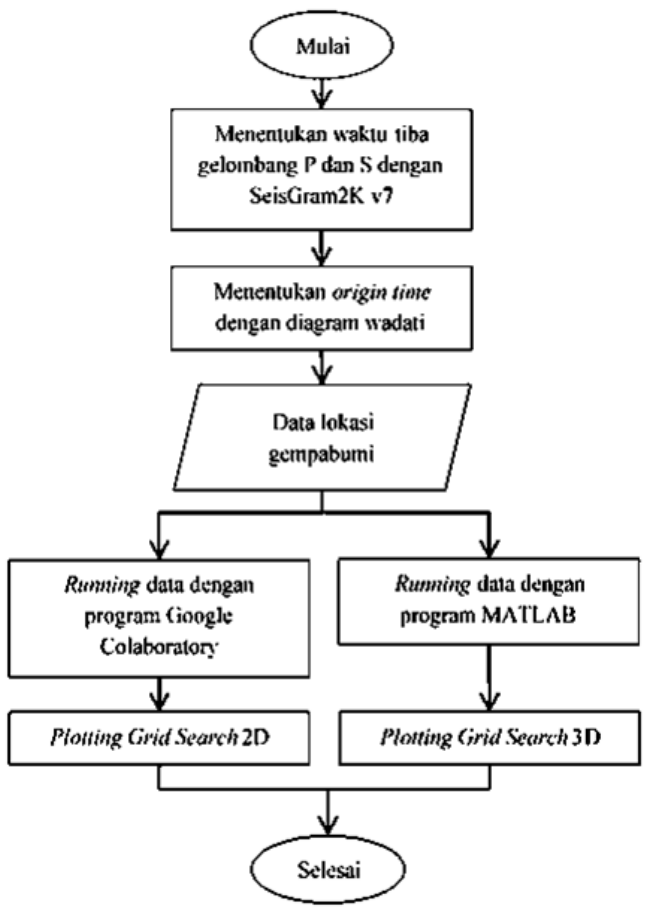

Gambar 2. Tahapan Penelitian. 


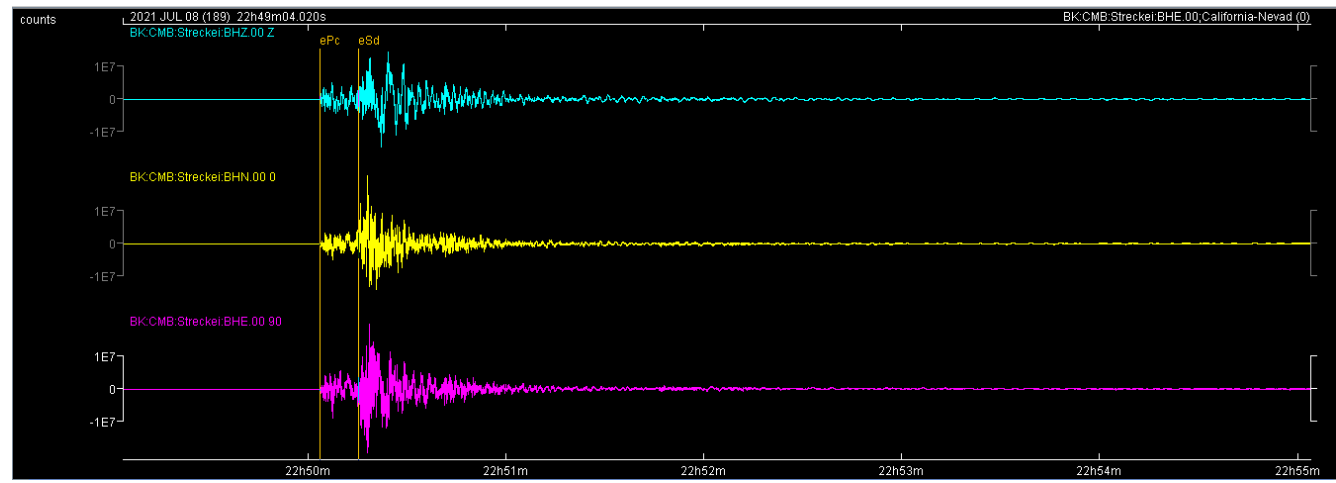

(a)

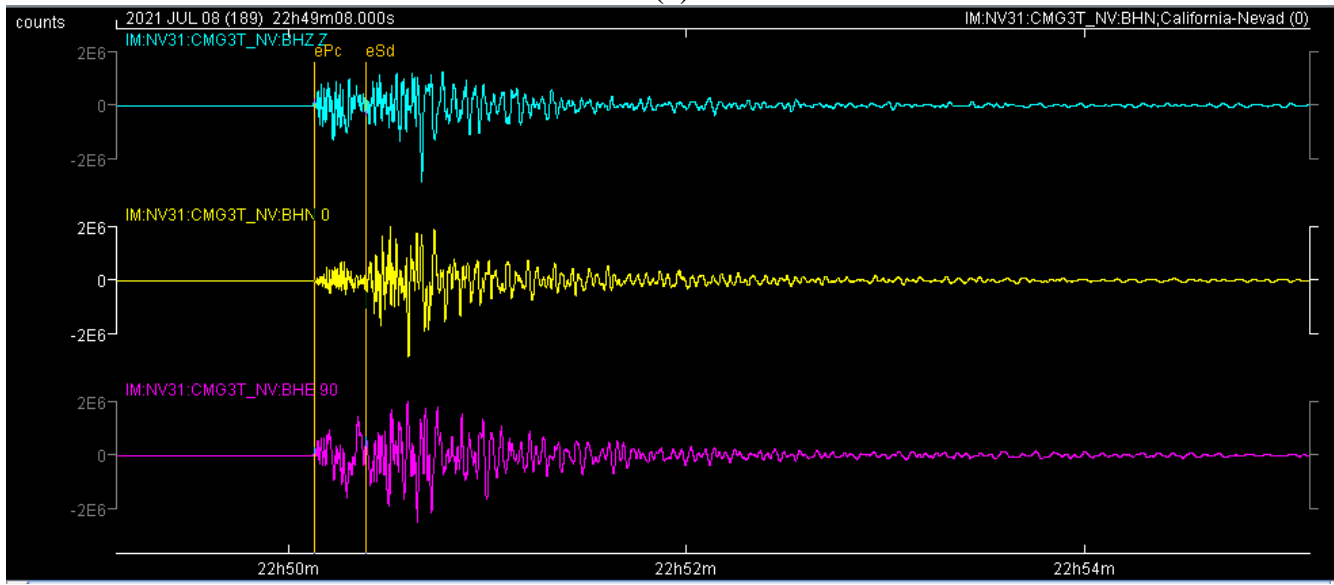

(b)

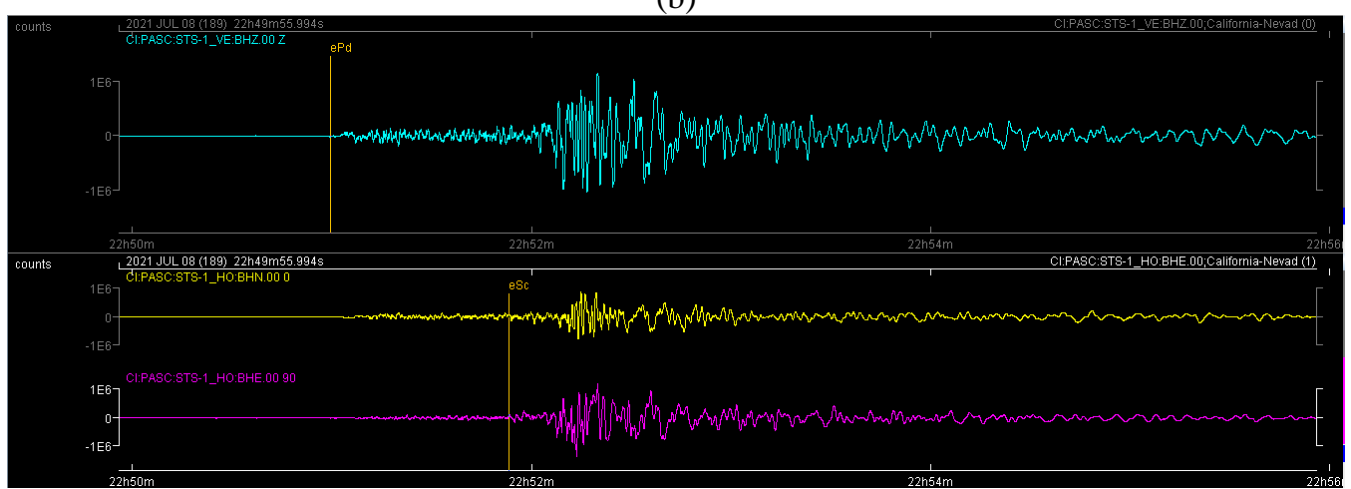

(c)

Gambar 3. Hasil picking gelombang P dan S pada stasiun (a) CMB, (b) NV31, (c) PASC.

Sebelum melakukan pengolahan data menggunakan Grid Search, maka harus ditentukan terlebih dahulu interval waktu tiba gelombang $\mathrm{P}$ dan gelombang S. Proses penentuan tersebut menggunakan SeisGram2K v7 dengan cara picking fasa gelombang $\mathrm{P}$ dan $\mathrm{S}$. Adapun hasil picking gelombang $\mathrm{P}$ dan $\mathrm{S}$ dari ketiga stasiun ditunjukan pada Gambar 3.

Berdasarkan hasil picking fasa gelombang $\mathrm{P}$ dan $\mathrm{S}$ dari ketiga stasiun pada Gambar 3 dapat diperoleh tabel hasil perhitungan sebagai berikut (Tabel 1),
Tabel 1. Interval waktu tiba gelombang P dan S.

\begin{tabular}{cccc} 
Stasiun & Tp & Ts & Ts-Tp \\
\hline CMB & $22: 50: 03,654$ & $22: 50: 15,280$ & 11.626 \\
\hline PASC & $22: 50: 59,430$ & $22: 51: 53,324$ & 53.894 \\
\hline NV31 & $22: 50: 07,776$ & $22: 5023,264$ & 15.488 \\
\hline
\end{tabular}

Tahap selanjutnya adalah menentukan nilai origin time dari gempa menggunakan Diagram Wadati, sehingga diperoleh grafik sebagai berikut (Gambar 4): 


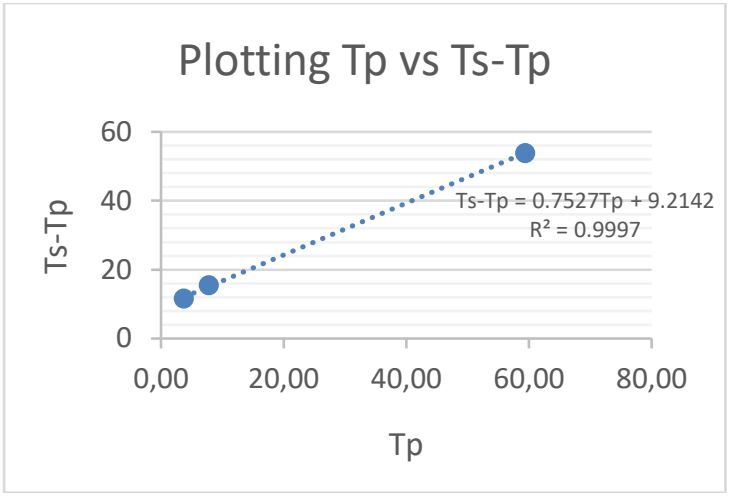

Gambar 4. Grafik hubungan Tp vs Ts-Tp.

Berdasarkan Gambar 4. diperoleh bahwa formula $\mathrm{Ts}-\mathrm{Tp}=0,7527 \mathrm{Tp}+9,2142$ menunjukkan nilai koefisien determinasi sebesar 0,9997, mengikuti keterangan pada sumbu X adalah Tp atau $t_{i}^{\text {obs }}$ dan sumbu Y adalah Ts-Tp (interval waktu tiba gelombang $\mathrm{S}$ dan $\mathrm{P}$ ) diperoleh parameter origin time, yaitu 10:49:48 PM.

\section{Hasil dan Pembahasan}

Pemakaian metode Grid Search dapat dilakukan proses penentuan episenter dengan tampilan 2D dan hiposenter dengan tampilan 3D untuk menentukan lokasi gempa, dengan adanya origin time sebagai parameter pedeteksian titik gempa. Berikut adalah hasil perhitungan episenter menggunakan metode Grid Search 2D:

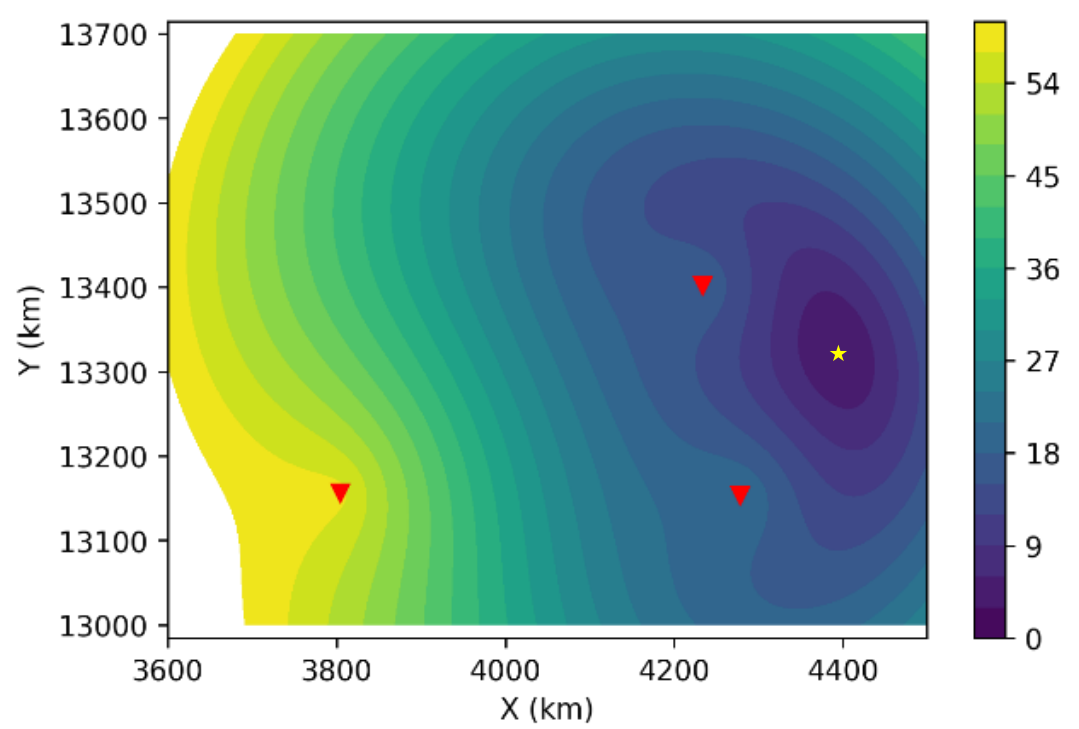

Gambar 5. Hasil relokasi episenter gempa (bintang kuning) beserta letak stasiun gempa (segitiga merah) dengan metode Grid Search 2D.

Berdasarkan Gambar 5 diperoleh perkiraan posisi episenter berada di sumbu X (garis lintang) $4370 \mathrm{~km}$ dan sumbu Y (garis bujur) pada $13340 \mathrm{~km}$. Perkiraan posisi episenter tersebut diperoleh karena memiliki nilai error RMS yang paling kecil, yakni sebesar 0-1 detik (warna ungu tua). Hasil posisi episenter tersebut masih dalam bentuk kilometer, sehingga untuk mendapatkan dalam bentuk derajat perlu dilakukan konversi sehingga diperoleh nilai lintang $39,255^{\circ}$ LU dan bujur $119,833^{\circ}$ BB. Hasil perkiraan tersebut masih belum cukup dijadikan parameter dalam penentuan posisi hiposenter gempa yang akurat karena belum memiliki komponen kedalaman. Akan tetapi dengan nilai error RMS yang kecil maka dapat digunakan sebagai penentuan awal lokasi episenter gempa yang kemudian akan dikombinasikan dengan metode Grid Search 3D unuk menentukan hiposenter gempa. Penentuan hiposenter gempa menggunakan Grid Search 3D dengan menerapkan pendekatan inversi non-linear diperoleh hasil sebagai berikut: 


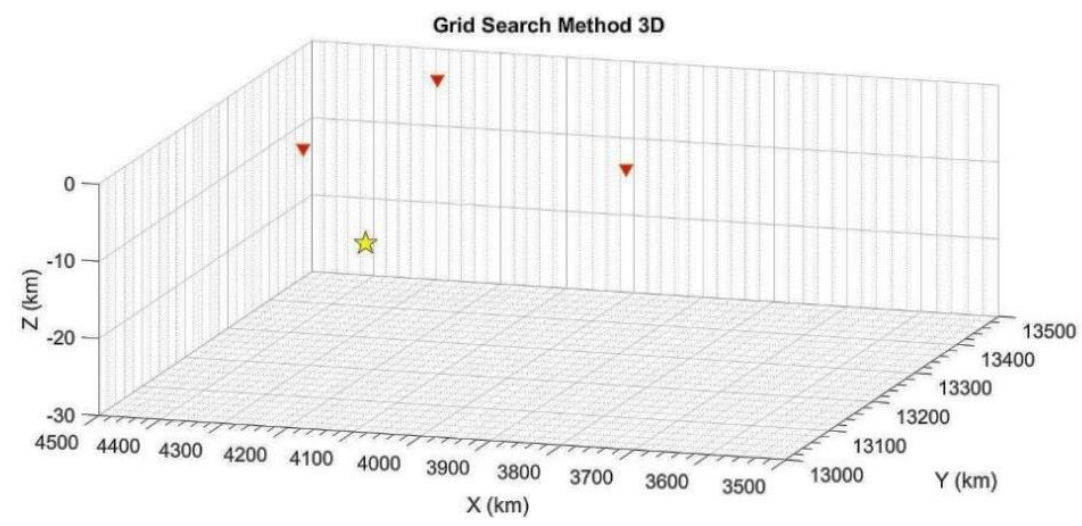

(a)

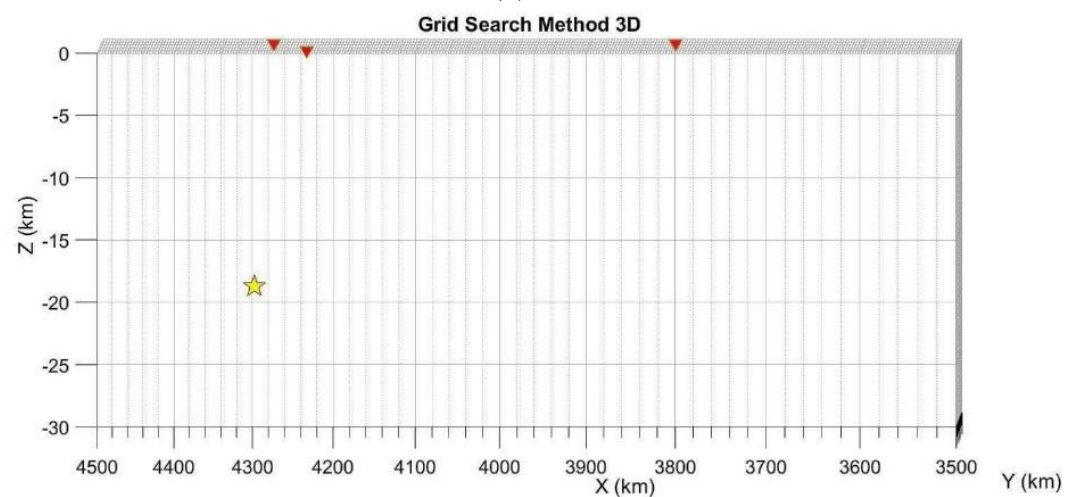

(b)

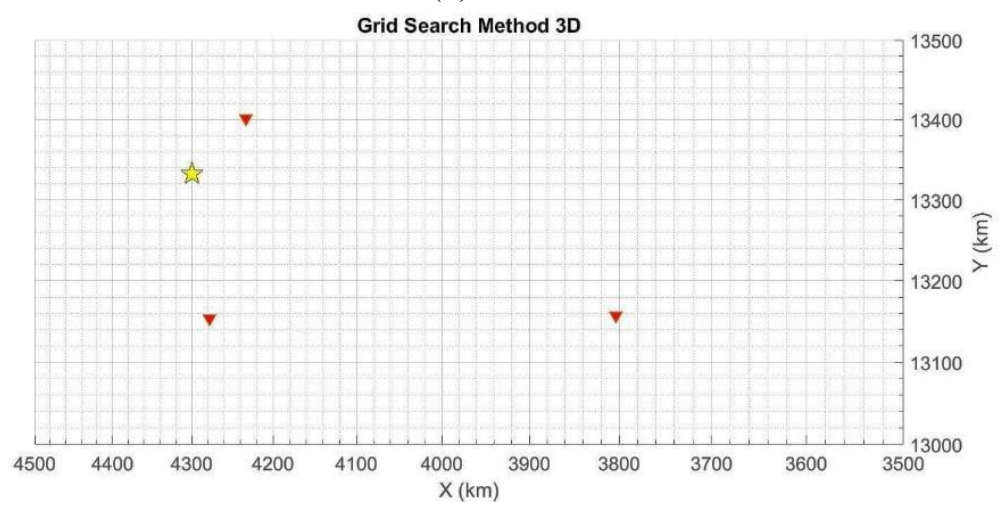

(c)

Gambar 6. Hasil relokasi hiposenter gempa (bintang kuning) beserta stasiun gempa (segitiga merah) dengan metode Grid Search 3D tampak (a) seluruh, (b) samping, (c) atas.

Hasil penentuan hiposenter gempa menggunakan Grid Search 3D pada Gambar 6 dapat diketahui bahwa sumbu X (West-East) adalah garis lintang dalam $\mathrm{km}$, sumbu Y (North-South) adalah garis bujur dalam km, dan sumbu Z (Depth) adalah zona kedalaman yang membentuk ruang relokasi titik hiposenter. Simbolisasi bintang berwarna kuning menandakan titik hiposenter dan segitiga berwarna merah menandakan posisi stasiun gempa bumi. Titik hiposenter berada pada garis lintang
$4300 \mathrm{~km}$, garis bujur $13335 \mathrm{~km}$ dan pada kedalaman $18 \mathrm{~km}$. Apabila dikonversi dalam derajat maka diperoleh nilai lintang $38,627^{\circ} \mathrm{LU}$, bujur $119,788^{\circ} \mathrm{BB}$. Nilai error RMS seperti pada Gambar 7.

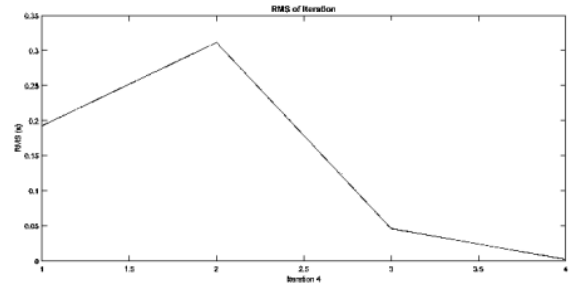

Gambar 7. Grafik Error RMS Metode Grid Search 3D. 
Berdasarkan hasil perhitungan relokasi diperoleh titik hiposenter gempa pada lintang $38,627^{\circ} \mathrm{LU}$, bujur $119,788^{\circ} \mathrm{BB}$ dengan kedalaman $18 \mathrm{~km}$ serta titik episenter gempa pada lintang $39,255^{\circ} \mathrm{LU}$ dan bujur $119,833^{\circ} \mathrm{BB}$. Hasil perhitungan dapat dirujuk kepada data USGS sebagai validasi. Data USGS menyatakan bahwa lokasi hiposenter gempa pada lintang $38,508^{\circ} \mathrm{LU}$, bujur $119,500^{\circ} \mathrm{BB}$, dan di kedalaman $7,5 \mathrm{~km}$. Terdapat selisih episenter $0,747^{\circ} \mathrm{LU}$ dan $0,333^{\circ} \mathrm{BB}$ dari data hasil.

\section{Kesimpulan}

1. Berdasarkan pengolahan dengan Metode Grid Search secara 2D dan 3D maka didapatkan posisi hiposenter relokasi berada pada lintang $38,627^{\circ} \mathrm{LU}$, bujur $119,788^{\circ} \mathrm{BB}$ dan kedalaman $18 \mathrm{Km}$. Sedangkan berdasarkan data USGS, hiposenter gempa berada pada lintang $38,508^{\circ} \mathrm{LU}$, bujur $119,500^{\circ} \mathrm{BB}$ dan kedalaman 7,5 km.

2. Pada penentuan posisi episenter gempa bumi menggunakan Metode Grid Search 2D didapatkan selisih episenter $0,747^{\circ}$ LU dan $0,333^{\circ}$ BB dari data acuan (USGS), artinya penggunaan Metode Grid Search 2D dapat digunakan sebagai penentuan posisi episenter yang sesungguhnya.

3. Penentuan posisi episenter dan hiposenter tidak dapat dilakukan menggunakan Metode Grid Search saja, akan tetapi harus dilengkapi pendekatan inversi secara non-linear terutama pada Metode Grid Search 3D. Hal ini dilakukan untuk mendapatkan nilai kedalaman gempa yang memiliki error tidak terlalu jauh dengan yang sesungguhnya.

\section{Ucapan Terima Kasih}

Terima kasih kami ucapkan kepada IRIS (Incorporated Research Institutions for Seismology) sebagai penyedia sumber data. Kemudian, kepada USGS (United States
Geological Survey) atas pengaksesan data gempa. Juga kepada rekan - rekan satu penelitian yang sudah saling membantu menyelesaikan dan menyusun penelitian ini hingga selesai.

\section{Daftar Pustaka}

Arimuko, A., Yoga, D.P., dan Hendri, S. 2019. Model Kecepatan 1-D Gelombang $P$ dan Gelombang $S$ dari Data Hasil Relokasi Hiposenter di Wilayah Gunung Sinabung. Jurnal Meteorologi Klimatologi dan Geofisika 5(3), pp.1-10. doi: https://doi.org/10.36754/jmkg.v5i3. $\underline{77}$

Decourten, F. 2008. Geology of Northern California. Department of Earth Science Sierra College. USGS.

Grandis, H. 2009. Pengantar Pemodelan Inversi Geofisika. Edisi ke-1. Bandung: Himpunan Ahli Geofisika Indonesia.

Kusuma, A.T. 2018. Penentuan Zona Reservoir Menggunakan Data Magnetotelluric (MT), Microearthquake (MEQ) dan Metode Fault and Fracture Density (FFD) Pada Lapangan Panasbumi "ITE" Provinsi Nusa Tenggara Timur. Skripsi. Fakultas Teknologi Kebumian dan Energi Universitas Trisakti, Jakarta.

Nugroho, H., Widiyantoro, S., dan Ibrahim, G. 2007. Penentuan Posisi Hiposenter Gempa bumi Dengan Menggunakan Metoda Guided Grid Search Dan Model Struktur Kecepatan Tiga Dimensi. Jurnal Meteorologi Dan Geofisika, 8(1), pp.48-60. https://doi.org/10.31172/jmg.v8i1

Palupi, I.R., dan Raharjo, W. 2020. Studi Automatic Picking Waktu Tiba Gelombang $P$ dan $S$ dengan menggunakan Spektogram pada Obspy Python. Jurnal Teori dan Aplikasi Fisika. 8(1), pp.77-83. 
https://doi.org/10.23960/JTAF.V8I $\underline{1.2433}$

Rysnawati, N.M., Sukarasa, I.M., dan Paramarta, I.D.A. 2017. Analisa Tingkat Bahaya dan Kerentanan Bencana Gempa Bumi di Wilayah Nusa Tenggara Timur (NTT). Buletin Fisika. 6(1), pp.32-37. https://doi.org/10.24843/BF.2017.v 18.i01.p06

Rahman, Y.Y. dan Santosa, B.J. 2013. Relokasi Hiposenter Gempa Bumi di Sumatera Selatan dengan Menggunakan Hypo71. Jurnal Sains dan Seni Pomits. 2(2), pp.82-86. https://doi.org/10.12962/j23373520 . $\mathrm{v} 2 \mathrm{i} 2.4278$

Sunarjo., Gunawan, M.T., dan Pribadi, S. 2012. Gempa Bumi Edisi Populer. Edisi ke-1. Jakarta: Badan Meteorologi Klimatologi dan Geofisika.

Tanjung, N.A.F. 2018. Pemodelan Zona Subduksi Lempeng Gorda Dan Area Great Basin di California, Nevada, dan Utah Berdasarkan Data Anomali Gravitasi Satelit. Disertasi. Universitas Gadjah Mada.

Unruh, J., Humphrey, J., and Barron, A. 2003. Transtensional model for the Sierra Nevada frontal fault system, eastern California. Geology. 31(4), pp.327-330.

https://doi.org/10.1130/00917613(2003)031\%3C0327:TMFTS N\%3E2.0.CO;2 